Portland State University

PDXScholar

1976

The No-fault dissolution of marriage act in Oregon: a study of its effect on selected factors

Dennis Arthur Armstrong

Portland State University

Follow this and additional works at: https://pdxscholar.library.pdx.edu/open_access_etds

Part of the Social Work Commons

Let us know how access to this document benefits you.

Recommended Citation

Armstrong, Dennis Arthur, "The No-fault dissolution of marriage act in Oregon: a study of its effect on selected factors" (1976). Dissertations and Theses. Paper 2144.

https://doi.org/10.15760/etd.2142

This Thesis is brought to you for free and open access. It has been accepted for inclusion in Dissertations and Theses by an authorized administrator of PDXScholar. Please contact us if we can make this document more accessible: pdxscholar@pdx.edu. 


\section{THE NO-FAULT DISSOLUTION OF MARRIAGE ACT IN OREGON: \\ A STUDY OF ITS EFFECT ON SELECTED FACTORS}

by

DENNIS ARTHUR ARMSTRONG

A research practicum submitted in partial fulfillment

of the requirements for the degree of

MASTER OF SOCIAL WORK

Portland State University

1976 


\section{ACKNOWLEDGMENTS}

I wish to express my thanks and appreciation to Donald G. Welch, Director, Department of Family Services, for allowing me to use the facilities and resources of the Department for my research.

I also wish to express my thanks to all of the staff of the Department for their interest, encouragement, and support. 
TABLE OF CONTENTS

PAGE

ACKNOWLEDGMENTS.$\cdot \cdot \cdot \cdot \cdot \cdot \cdot \cdot \cdot \cdot \cdot \cdot \cdot \cdot \cdot$

CHAPTER

I INTRODUCTION . . . . . . . . . . 1

The Purpose of the Study . . . . . 1

The Change in the Law ....... 2

Abolishing Fault-related Grounds

Admissability of Evidence Relating to Conduct

Terminology

Residency Requirements

Encouraging Collusion

The value of this study . . . . 5

II REVIEW OF THE IITERATURE . . . . . . 7

The Coming of No-Fault Legislation . . 7

After No-Fault Divorce . . . . . 9

III METHOD . . . . . . . . . . .

The Samples . . . . . . . 13

Sampling the Legal Files

Defining the Variables

Conciliation Statistics

The Hypothesis . . . . . . .

Underlying Assumption

Central Hypothesis

Sub-hypotheses 
CHAPTER

PAGE

Analysis of the Data . . . . . 17

IV FINDINGS . . . . . . . . . . 19

The Conciliation Sample . . . . 19

Analysis of the Legal Files Sample • . 20

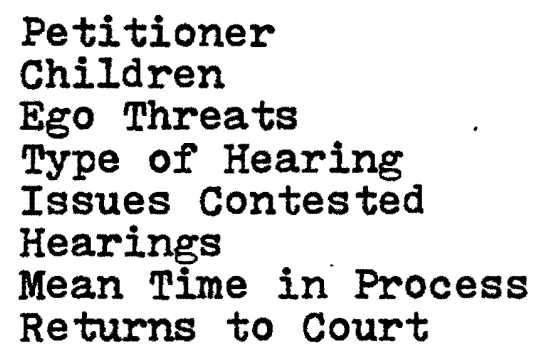

Other Factors with Returns to Court. .

25

$\checkmark$ IIMITATIONS, CONCLUSIONS, AND SUGGESTIONS FOR FURTHER RESEARCH .... 30

Iimitations . . . . . . . 30

Conclusions . . . . . . . 31

Suggestions for Further Research •. • 32

BEFERENCES CONSULTED . . . . . . . . . . 33 


\section{LIST OF TABLES}

TABIE

PAGE

I Distribution of Outcomes: Comparing 1970

and 1972 Couples Seeking Marriage

Counseling at Family Services Agency,

Dissolution Filed . . . . . . .

II Data Comparison from the 1969 and 1972 Samples

of the Fourth Judicial District Circuit

Court of Oregon Dissolution Files . .

III Chi Square: Relationship Between the Presence or Absence of Children and the Change in the Law . . . . . . . . .

IV Chi Square: Relationship Between the Proportion of Ego Threats and the Change in the Law . . . . . . . . .

V Chi Square: Relationship Between the Proportion of Cases Requiring Multiple Hearings and the Change in the Law . .

VI Comparison of the Mean. Standard Deviation, and Sample Size of Months in Process of 1969 and 1972 Dissolution Cases ...

VII Chi Square: Relationship Between the Presence of Children and Returns to Court . . . 
VIII Chi Square: Relationship Between Ego Threats and Returns to Court......

IX Chi Square: Relationship Between Contests and Returns to Court . . . . . . .

X Chi Square, Relationship Between Multiple Hearings and Returns to Court . . . . 
CHAPTER I

INTRODUCTION

In October of 1972, the Dissolution of Marriage Act (hereinafter referred to as the Act) became a part of the law and judicial practice of the state of oregon. The Act represents a significant change in Oregon's law. It also represents a significant evolutionary development in the attitude of the legal community toward the process of divorce or, as it is now termed, dissolution of marriage.

\section{THE PURPOSE OF THE STUDY}

The Act was a response to extensive criticism from professionals and from the public. The problem is the legislators were not sure of the effects of the Act, and now that it is in effect there is still little or no objective data regarding its effectiveness. This study is an exploratory attempt to evaluate the consequences of the Act, the accomplishment of its stated purposes, and its impact upon the process of dissolution and the people involved.

I hope to find if such legislation helps to mitigate the social cost of dissolution. I also hope to substantiate the interrelatedness of some of the events within the process in order to stimulate further research which may be relevant to legislators, judges, attorneys, and mental health prac- 
titioners in their efforts to deal effectively with the breakup of families.

\section{THE CHANGE IN THE ILAW}

Prior to the implementing of the Act in 1972, Oregon's divorce law was based on the adversary system. The courts awarded a Decree of Divorce to one or both parties upon their presentation of proof of one or more of seven admissable "grounds for divorce." The parties were protagonists and fault was to be determined by the court. Collusion of parties was illegal and was a basis for dismissal of the complaint. The person filing for divorce was called the plaintiff and his or her spouse became the defendant. Evidence of conduct of the parties was admissable for any of the decisions to be made by the court.

Bateman, et al. (1970) provides a comprehensive review of the history of divorce, the adversary process, the grounds for divorce, and the status of divorce procedure in oregon in 1970. As she notes, the practice of the courts was different from the way the law was actually written. The overwhelming majority of cases were initiated on the grounds of "cruel and inhuman treatment," and roughly ninety per cent of the decrees were granted in default. In default cases, the par-. ties have agreed to the details of the settlement and the defendant does not usually appear at the final hearing. The Act attempts to abolish the concept of fault and 
the adversary process. Specific changes include:

1. Abolishing fault-related grounds.

2. Admissability of evidence relating to: conduct.

3. Terminology.

4. Residency requirements.

5. Encouraging collusion.

Abolishing Fault-related Grounds

Impotency, adultery, felony conviction, and the rest of the seven charges that were grounds for divorce under the former statute are all abolished by the Act. The sole issue replacing those is "Irreconcilable differences between the parties have caused the irremediable breakdown of the marriage." The court now simply attempts to determine whether the marriage relationship is salvageable. If the court agrees that the marriage breakdown is indeed irremediable, a Decree of Dissolution of Marriage is issued and the marriage terminated without proof of guilt of the parties becoming an issue.

Admissability of Evidence Relating to Conduct

Even though the granting of a Decree of Dissolution does not hinge upon the establishment of fault, there is still one area in which evidence relating to conduct is admissable under the Act. When the custody of minor children is at issue, the court will accept evidence relating to the conduct of the parties provided that such evidence relates 
either to the determination of the parent's suitability for custody or to the protection of the financial interests of the children.

\section{Terminology}

In addition to removing the potential antagonism of the fault-related grounds, the Act substitutes neutral words for many of the terms used in the proceedings that connotatively contribute to the feeling of combat between spouses. Some examples are the substitution of Petition for Complaint, Petitioner for Plaintiff, Respondent for Defendant, and Dissolution of Marriage in place of the emotionally loaded word Divorce.

\section{Residency Requirements}

The required period of time for residing in oregon before legally filing for dissolution was reduced from one year to six months. The waiting period between the date of filing and the issuance of the decree remains at the minimum of ninety days. Also unchanged is the sixty day wait pursuant to the decree before it becomes final. During this time, the decree may be voided by joint consent of the parties

Encouraging Collusion

Under earlier law, collusion was illegal. The Act not only legalizes it, but promotes it. The parties are 
encouraged to arrange their own settlements and to plan for the interests of their children. Actually, this does not represent a very real change from the way the courts treated this issue already. However, it does remove both judges and attorneys from the ethical bind of having to almost continually ignore a desirable process that was still illegal.

\section{THE VALUE OF THIS STUDY}

The changes in the law presented here seem to me to be coherent, rational, and useful alterations. It is the task of the social scientist, however, to devise ways to test the apparent worth of such steps and not to rely entirely upon the logical sound of them. According to a statistician for the Fourth Judicial District of the Circuit Court of Oregon, there were 5,572 petitions for the dissolution filed in 1972 in Multnomah County. He repprts that the number increases each year. The social costs of a problem affecting that many families each year must be evident to the pragmatist as well as the humanist. To the humanist, dissolution of marriage is an emotionally catastrophic event involving great personal loss to the individuals. It is accompanied by much conflict and involves extensive readjustment of the individuals' way of life. To the pragmatist, the financial burdens for part of that process are very real. Social institutions often bear all or part of the financial responsibility for children after a family breaks up. 
The courts certainly take a concrete portion of the tax dollar.

Ours is a family based culture. . Any legislation. proposal, or program which aims at dealing with the breakup of families deserves the closest attention. We must check to see if what has been done has value. If it has none, it must be changed. If it has value, it can be improved with the knowledge gained in the testing. The value of this study is in being a part of that process. 
CHAPTER II

\section{REVIEW OF THE IITERATURE}

I gained a fairly thorough familiarity with the general body of literature on the subject of divorce while I worked as a consultant to the Domestic Court in Multnomah County from 1972 to 1975. Much has been written about various aspects of divorce. Very little has been written on other aspects of the same topic. I felt certain that I would find adequate references regarding the criticisms of adversary domestic law and the trend of thinking that led to the Act. I was equally certain that I would find very little objective information about the effects of nofault legislation. My survey verified those beliefs.

\section{THE COMING OF NO-FAULT LEGISIATION}

In 1969, the National Conference of Commissioners on Uniform State Laws approved a model bill entitled the Uniform Marriage and Divorce Act. This model bill proposed abolishing the adversary process in divorce and substituting breakdown of marriage for the traditional fault-related grounds. By the end of 1972, eight states had passed laws cantaining that principle, several others had added breakdown of marriage to their existing grounds, and most of the other states were considering one form or another of 
similar legislation.

Wheeler (1974), quoting the California Governor's Commission on the Family, suggests a need for such legislation.

In addition to simplifying the procedures and permitting the proper full inquiry by the court, the removal of the specific fault ground and the adoption of a 'breakdown of marriage' standard will eliminate much of the adversary aspect of divorce litigation by removing the need for specific accusation and answer. It will prevent the use of misconduct not formally alleged as a bludgeon (by threat of its disclosure) in obtaining extortion concessions concerning support and the division of property from the opposing spouse concessions which are frequently inequitable and unworkable, and which do not represent any true agreement. Moreover, it will put an end to the dissimulation, hypocrisy - and even outright perjury - which is engendered by the present system.

Ron Gevurtz, a prominent Portland attorney in the practice of domestic law, described in a personal interview how he saw Oregon's no-fault law as a legislative response to bombardment by humanists. According to Gevurtz, proponents of the Act used the reasons given in the above quote. Humphrey (1972) writes that rigid rules for divorce serve "only to exacerbate underlying feelings of animosity and scorn." He and others also make very clear that divorce by consent is absolutely unacceptable. He sees the concept of "irretrievable breakdown.". as a compromise between the adversary process and divorce by consent.

Cline and Westman (1971) underline the need for change, pointing out how feelings of animosity are sometimes translated into assault, child abduction, and post-divorce murder. 
Crowe and Harrington (1971), commenting on the purposes of the Act, writes

The traditional concept of divorce based on fault has been singled out as an ineffective barrier to marriage dissolution. which is regularly overcome by perjury and thus promotes disrespect for the law and its processes, and as an unfortunate device which adds to the bitterness and hostility of divorce proceedings.

I have quoted only a few sources, but the same issues recur throughout the literature. Legislators, attorneys, and social scientists all seem to agree that traditional divorce Iegislation-fostered circumventing of the law and added to the hostilities between parties to the divorce. Wheeler (1974), in his chapter on "The Politics of Reform," makes a comment that sums up the social atmosphere.

Across the country there seems to be a sense that our divorce laws are outmoded and serve no useful purpose. Whether or not this proposition can be scientifically proven - public opinion polls on such issues as divorce are of dubious value - it does seem as if only a minority of the population is steadfastly opposed to any revision of the laws. People may not be sure of what must be done, but there is a general feeling that reform is in order.

\section{APTER NO-FAULT DIVORCE}

Howard Krom (1970), Director of the California Department of Public Health Bureau of Vital Statistics, points out, "...substantive information relative to divorce is conspicuous by its absence." This seems to be particularly true with regard to statistically testable data from studies which examine factors within the process of divorce. 
Lena Heritage (1972), in her dissertation, attempted to isolate factors and their effect on post-divorce adjustment. Unfortunately, she was relatively unsuccessful in her attempt to isolate significant variables. This suggest the difficulty of research in this area and may partially account for the paucity of written material that includes helpful substantive information.

Wheeler (1974) includes a few statistics in his book on no-fault divorce. He reports that the divorce rate rose $46 \%$ in 1970, the first year of California!s reformed law, dipped slightly the next year, and rose slightly again the year after that. Interestingly enough, Oregon statistics showed no such dramatic increase. The rate is climbing, but the passage of the Act did not significantly affect, the slow, steady increase in divorce statistics of the past few years.

Wheeler (1974) reports certain other apparent effects of the no-fault legislation in California. In 1970, the divorce rate in Nevada dropped 15\%. Wheeler estimates a rise in the percentage of persons filing for divorce without the aid of an attorney. Roughly 1\% filed that way before, and the rate since 1970 has been about 5\%. A direct relationship has not been established, but wheeler thinks also that California judges have begun to lower the amounts they award for alimony and settlements since 1970.

Goddard (1972) reports the effects similarly. He also reports an increase in the proportion of husbands filing for 
divorce. Basing his study upon interviews with judges, Goddard also mentions that they seem to be relatively pleased with the time-saving effect of the law.

Zuckman and Fox (1972) describe many of the above elements as short term effects of the 1970 California law. However, they add a very interesting possibility to the list. They, feel that the traditional law with its fault-related grounds lent a therapeutic cathartic effect to the divorce process. Under the new law, this cathartic effect has, they believe, been diminished.

Judge Harlow Lenon of Multnomah County, discussed his impressions of the effects of the oregon no-fault law in a personal interview. He believes that it has significantly reduced court time. He, like Zuckman and Fox, believes that no-fault has removed a therapeutic discharge from the divorce process. He further states the inadmissability of evidence relating to conduct rule and the changing moral climate have combined to increase the capacity for husbands to advance their causes in court.

Judge Jean Lewis of Multnomah County, speaking in a personal interview, corroborated that last statement. She reports more property fights because men no longer have to buy their freedom. She believes that most of these property fights require less time than previously, but the complicated cases actually take longer.

Victoria Stevenson (1976), a third year law student at 
the University of Oregon, has performed the only study of the results of the Act in Oregon to date. She obtained the bulk of her data through interviews with various domestic court judges. She reports increased litigation and attributes it to the reduction of risk that the parties' past conduct will be exposed. She cites statistics from four counties from 1970 and 1973 which show a change from 4.2\% to $6.5 \%$ in the percentage of cases which are contested. The benefits of no-fault have not materialized according to Stevenson. She believes catharsis is unavoidable and some judges are allowing the process to continue as before the no-fault rule. She concludes that oregon would be better off if we returned to the fault system until judges could delete their ingrained biases toward establishing fault from their handing of the dissolution process. 
METHOD

I wanted to evaluate the impact of the Act on people in the dissolution process. Accordingly, I drew samples of selected variables from time periods before and after the implementation of the Act. I compared the samples of the time periods for differences in the variables. I then tested for the significance of those differences.

\section{THE SAMPLES}

I drew data from two separate sources. The source of the main body of data was the legal files of divorce cases of the Fourth Judicial District of the Circuit Court of Oregon, which provides services to the residents of Multnomah County. Secondarily, I used certain statistics from the conciliation files of the Department of Family Services, a public agency that provides conciliation services to the residents of Muztnomah County and consultant services to the court. For those who wish to become more specifically familiar with the Family Services Agency, Brune, et al. (1970) provides a detailed description of the development and functions of the agency and its relationship to the court. 
Sampling the Legal Files

I chose to compare data from 1969 with data from 1972. I chose 1972 because I wished to check each case a full two years after the decree was issued to record the number of cases which required returns to court. I chose 1969 to ensure that no cases of extraordinary longevity were decided under the no-fault rule. Because the Act was implemented in the autumn of 1972, it was necessary to limit the 1972 sample to cases filed in November or December. I applied this same limitation to the 1969 sample to assure consistency.

The court maintains lists of each years' divorce cases in large hardbound volumes. The volumes are divided alphabetically into 99 approximately equal sections. The names and numbers of the cases in each section are entered by chronological order of filing. I assigned each section a number from 1 through 99. Using a table of random numbers, I selected 50 sections. I arbitrarily chose the last 6 entries in each section from which to draw the case numbers. This ensured that the cases were from November and December of the sample years. I then threw a die 50 times to select the cases from the group of 6 in each section. This process left me with 3 duplications of cases. I resolved this by 3 more tosses of the die.

\section{Defining the Variables}

The information I wanted was contained in the legal forms, documents, court orders, affidavits, motions, and 
other papers that accrue in a divorce file as it goes through the court process. I drew a trial sample of 10 cases, 5 from each year, to gain a clearer idea of the information which would be consistently available from this source. With this information I devised a simple data sheet for recording the variables I will discuss below.

Petitioner. Under this heading I recorded the sex of the person filing for dissolution.

Children. I recorded the number of children in this column. However, I was more interested in separating couples with no children from families including children. Ego Threats. I noted the presence or absence of egothreatening statements in each case. I defined ego-threats to be statements in papers filed to the court, of a specific accusatory nature, and relating to the conduct of the spouse which, if accepted as true, would result in loss of self esteen by the spouse. Some examples are desertion, alcoholism, child beating, etc..

Type of Final Hearing. There are three types of final hearings at which the decree is granted. A default is a case in which there were no issues left unresolved at the time of the final hearing. Most often only the filing party is present at the hearing. Although legally different, a prima facie case is, for purposes of this study, similar to a default and was included in that category. A contest is a case which comes to court for the final hearing with issues 
unresolved and to be decided by the court. In a dismissal, the parties remain married, and the suit is withdrawn. These were noted also in this section.

Issues Contested. Of those cases contested, I noted whether the issues were children, property, or both. Multiple Hearings. I differentiated between cases with a single hearing and those with multiple hearings. Time in Process. I recorded the length of time in months between the date of filing and the date of the final hearing •

Returns to Court. I noted the cases which returned to court for further litigation during the first two years following issuance of the decree.

\section{Conciliation Statistics}

The second data source was a statistical record kept by the Department of Family Services. I recorded the total population, for 1970 and 1973, of cases in which a Petition for Reconciliation, a formal application for marriage counseling, was filed; and where a Petition for Dissolution was already filed with the court. I then recorded the number of cases marked RE (reconciliation effected), RR (reconciliation rejected), and os (outcome unknown). This provided the proportions of those couples electing to remain married and those electing to terminate their marriages. These figures reflect the attitudes of the couples at the time of their last 
contact with the agency. They do not represent exactly the ultimate decisions they might make.

\section{THE HYPOTHESIS}

Underlying Assumption

I make the following underlying assumption in the formulation of my hypothesis If the implementation of the Act significantly removes negative impact upon the emotional dynamics of families in the divorce process, that change will be reflected in the statistics of the court-related behaviors of such families.

Central Hypothesis

The central hypothesis stated in null terms is: The Act had no significant impact on families going through the divorce process.

Sub-hypotheses

The sub-hypotheses are the comparisons of data from the two years for each of the variables described in the last chapter section. To avoid redundancy and ensure clarity, they will be stated along with the results in the following chapter.

\section{ANALYSIS OF THE DATA}

The variables are represented by numerical data. I arranged the data in tabular form and observed each variable 
for differences between the two years. Where appropriate, I tested the differences for significance using such tests as Chi Square and the Significance of the Difference Between Two Proportions. I elected to use the .05 level of confidence in the tests, since this is an exploratory study, and I do not wish to accept the null hypothesis prematurely. 
CHAPTER IV

\section{FINDINGS}

I. THE CONCIILATION SAMPLE

Many couples seek marital counseling after one of the parties has filed for dissolution. The Act purports to remove the negative effect of traditional law upon families already in trouble. Therefore, I developed the hypothesis that of those couples who seek counseling while a suit for dissolution is pending, a greater proportion will reconcile after filing under the Act than reconciled after filing under traditional law. Observation of Table I shows that no such increase occurred, and the hypothesis is not accepted. I tested the observed decrease with the test of Significance of the Difference Between Proportions. I used the .05 level of confidence. The $\underline{z}$ score computed at .76 , indicating that the difference is not significant.

\section{TABLE I}

DISTRIBUTION OF OUTCOMES: COMPARING 1970 AND 1973

COUPLES SEEKING MARRIAGE COUNSELING

AT FAMILY SERVICES AGENCY, DISSOLUTION FILED 
II. ANALYSIS OF THE LEGAI FILES SAIMPLE

Observation of Table II shows the results of the 1969 sample compare very similarly with the 1972 sample. Upon preliminary comparison, the samples do not reveal enough differences to support a hypothesis that the Act significantly altered the impact of the process of dissolution of marriage on families. However, before accepting such a conclusion, each variable merits analysis and discussion.

\section{TABLE II}

DATA COMPARISON FROM THE 1969 AND 1972 SAMPLES

OF THE FOURTH JUDICIAL DISTRICT

CIRCUIT COURT OF OREGON

DISSOLUTION FILES

1. Petitioner

Husbands

Wives

2. Minor Children

Yes

No

3. Ego Threats

Yes

No

4. Type of Final Hearing

Default

Contest

Dismissal

Jurisdictional Transfer

5. Issues Contested

Child Custody

Property

Both Custody and Property

6. Hearings

Single

Multiple

7. Mean Time in Process (months)

8. Returns to Court

14

36

31

19

14

36

34

7

8

1

2

4

1

28

13
4.86

5.72

8

33
33

15

35

27

23

11

39

35

7

0

2

3

33

\section{.}

( 
Petitioner

I hypothesized that the removal of the necessity to prove fault might give rise to an increase in the proportion of husbands filing for dissolution. Observation of the first variable of Table II shows an increase of only 1 out.. of 50, clearly not a significant difference. It is also of interest to note that no couples in the 1972 sample took advantage of the Act's new provision for co-petitioning for dissolution of marriage.

\section{Chilaren}

Because the data showed an increase in the proportion of childless couples, I hypothesized that the decision to obtain a dissolution was easier to make for couples without children under the Act than before. I tested this by means of Chi Square. The Chi Square of the sample computed at .37. Chi Square at the .05 level with 1 degree of freedom is 3.84 , indicating rejection of the hypothesis (Table:III).

\section{TABLE III}

CHI SQUARE: RELATIONSHIP BETWEEN THE PRESENCE

OR ABSENCE OF CHIIDREN AND THE

$$
\text { CHANGE IN THE LAW }
$$

\begin{tabular}{lccr} 
Couples with Children & 31 & 27 & 58 \\
Couples with No Children & 19 & 23 & 42 \\
Total & 50 & 50 & 100 \\
\hline
\end{tabular}

$$
x^{2} \text { sample }=.37 \quad x^{2} .05,1 \text { df }=3.84
$$


Ego Threats

The data show a small decrease in the number of cases filed under the Act which contain ego threatening statements. Since one of the major changes in the law pertained to the removal. of adversary wording, I. hypothesized that the decrease in such cases is related to the implementation of the Act. I computed Chi Square to test this hypothesis. The computed Chi Square of the sample was .21. Chi Square at the .05 level with 1 degree of freedom is 3.84 , indicating that the difference in the samples occurred by chance, thus rejecting the hypothesis (Table IV).

\section{TABLE IV}

CHI SQUARE, RELATIONSHIP BETWEEN THE PROPORTION OF EGO THREATS AND THE CHANGE IN THE ILAW

1969 1972 Total

Ego Threats in the File 14 11 25 No Ego Threats in the File 36 39 75 Total 50 50 100

$$
x^{2} \text { sample }=.21 \quad x^{2} \cdot 05,1 \text { df }=3.84
$$

\section{Type of Hearing}

Observation (referring back to Table II) shows that the number of defaults, contests, and dismissals remained very nearly the same across the two samples. The differences will not support any but a null hypothesis. The difference between this result and the stevenson (1976) study, which 
shows an increase in the percentage of contested cases, can be explained. Her sample is actually the total population of dissolution cases for four counties. A sample of that : size will lend significance to a small change.

\section{Issues Contested}

The sample of contested cases, 7 for 1969 and 8 for 1972, is not large enough to permit analysis of the issues of the contests. It is interesting to note that no cases in 1969 were contested with the divorce being the sole issue.

\section{Hearings}

The samples show a decrease in the number of cases requiring multiple hearings in 1972. I hypothesized that a relationship exists between the implementation of the Act and the need for less hearings. I tested for the significance of this by means of Chi Square (Table V). For this

\section{TABLE V}

CHI SQUARE: RELATIONSHIP BETWEEN THE PROPORTION OF CASES REQUIRING MULTIPLE HEARINGS

AND THE CHANGE IN THE IAW

$$
1969
$$

13

28

41

$$
x^{2} \text { sample }=.39 \quad x^{2} .05,1 \text { df }=3.84
$$

test I omitted the cases which were dismissed and the 1 case 
transferred. Chi Square of the sample was computed at . 39 . Chi Square at the .05 level with 1 degree of freedom is 3.84, thereby refuting the hypothesis that the Act significantly reduced the incidence of cases requiring multiple hearings .

Mean Time in Process

The 19.72 sample showed a mean increase in the time in process of .86 months per completed case. I am not sure which of several factors the rising dissolution rate, the increasing percentage of contests, changes in court personnel, or some other unexplained effect of the Act, might account for the increase. Using the data in Table VI, I tested the hypothesis that the increase is significant.

TABLE VI

COMPARISON OF THE MEAN, STANDARD DEVIATION, AND SAMPLE SIZE OF MONTHS IN PROCESS

OF 1969 AND 1972 DISSOLUTION CASES

Months in Process 1969 1972

Mean

4.86

5.72

Standard Deviation

2.81

3.10

Sample Size

41

43

I used the test for the Significance of the Difference Between Sample Means. The sample sizes yield 82 degrees of freedom, allowing use of the normal curve. A $\underline{z}$ score of 1.645 or higher would be significant in a one-tailed test 
at the .05 confidence level. The computed $\underline{\mathbf{z}}$ score of the test was 1.327 . Therefore, the hypothesis that the increase is significant is rejected.

Returns to Court

Before I examined the data, I formed the hypothesis that the Act, by promoting collusion and by dilution of the adversary process, would reduce the proportion of cases that return to court for further litigation after the decree has been issued. However, observation of the samples indicates the number of returns to court diminished by only 1 case in the 1972 sample compared to the 1969 sample. A difference of 1 will not support a hypothesis that a relationship exists between the change in law and cases returning to court.

III. OTHER FACTORS WITH RETURNS TO COURT

Cases which return to court after issuance of the decree represent failure of the court process to bring resolution to relationships in crisis. I have formulated the hypothesis, not fully testable by this study, that there exists a sizable number of identifiable factors which have a testable relationship with cases that return to court. If extended research can isolate enough such factors, it may be possible to identify couples with a high risk for returning to court, and further, to reduce that risk.

Not to draw conclusions, but to stimulate research, I have tested for relationships between returns to court and 
some of the other variables isolated in this study. Since I had already tested each of the eight variables and found no significant differences, I decided it would be valid, as an exploratory method, to treat the 1969 and 1972 samples as one larger sample. I tested for these relationships by means of Chi square. I noticed while computing Chi Squares that the distribution of cases (15 cases returned to court, 84 did not return) sometimes left a theoretical frequency of less than 5 cases. This causes the computed Chi Square to lack validity. I will present the computed values anyway, since I am only attempting to stimulate research.

I first tested to see if there was a relationship between the sex of the petitioner and cases returning to court. Observation of the data indicated that the number of petitioner-husbands and petitioner-wives was spread proportionately across the cases returning to court. This indicated that there was no significant relationship.

I observed that $80 \%$ of those cases which returned to court were families with children. This led me to hypothesize that the presence of minor children would increase the likelihood of cases returning to court. The computed Chi Square of the sample was 2.64. Chi Square at the .05 level with 1 degree of freedom is 3.84. (Table VII). Although this result indicates that the above hypothesis is rejected, I observed while reading the legal files that most of the returns to court were to settle disputes over custody or 
visitation.

TABLE VII

CHI SQUARE: RELATIONSHIP BETWEEN THE PRESENCE OF CHIIDREN AND RETURNS TO COURT

Returns No Returns Total

\begin{tabular}{lrcr}
\hline Couples with Children & 12 & 45 & 57 \\
Couples with No Children & 3 & 39 & 42 \\
Total & 15 & 84 & 99 \\
\hline & $x^{2}$ sample $=2.64$ & $x^{2} .05,1$ df $=3.84$ &
\end{tabular}

It seemed very probable that a strong relationship would exist between ego threats and returns to court. I computed the Chi Square of this sample at 9.24. Chi Square at the .05 level with 1 degree of freedom is 3.84. Therefore, the test indicates that a significant relationship does exist between these two variables (Table VIII).

TABLE VIII

CHI SQUARE\& RELATIONSHIP BETWEEN EGO THREATS AND RETURNS

TO COURT

Returns No Returns Total

\begin{tabular}{lccc} 
Ego Threats & 9 & 16 & 25 \\
No Ego Threats & 6 & 68 & 74 \\
Total & 15 & 84 & 99 \\
\hline$x^{2}$ sample $=9.24$ & $x^{2} .05,1 \mathrm{df}=3.84$
\end{tabular}

Reasoning along the same line, I felt sure that cases 
which were contested at the time of dissolution were of significantly greater likelihood to return to court. However, the computed Chi Square of the sample was only 1.84, indicating that the apparent relationship between contested cases and returns to court is not statistically siginificant. Chi Square at the .05 level with 1 degree of freedom is equal to 3.84 (Table IX).

\section{TABIE IX}

CHI SQUARE: RELATIONSHIP BETWEEN CONTESTS AND RETURNS TO COURT

Returns

Contests

Defaults

Total
5

10

15 No Returns Total 10 15 69 59 84

$$
x^{2} \text { sample }=1.84 \quad x^{2} .05,1 \text { df }=3.84
$$

I tested the last variable, cases with multiple versus single hearings, to see if there was a relationship between multiple hearing cases and returns to court. The computed Chi Square of this sample was 15.93. Since Chi Square at the .05 level with 1 degree of freedom is equal to 3.84, the hypothesis that a significantly high percentage of cases which require multiple hearings during the dissolution process also require further litigation is accepted (See Table X). 
TABLE $X$

CHI SQUARE: RELATIONSHIP BETWEEN

MULTIPLE HEARINGS AND

RETURNS TO COURT

Returns

No Returns

Total

Multiple Hearing Cases

10

13

23

Single Hearing Cases

5

71

76

Total

15

84

99

$$
x^{2} \text { sample }=15.93 \quad x^{2} .05,1 \mathrm{df}=3.84
$$




\section{CHAPTER V}

\section{LIMITATIONS, CONCLUSIONS, AND SUGGESTIONS FOR FURTHER RESEARCH}

\section{LIMITATIONS}

The principle limitation of this study, and a source of frustration for myself, is that it includes no data from the members of families going through the painful process that the study purports to deal with. It is not that there is no value to the study of factors isolated from within the legal files. It is rather that any thorough study of this same topic must include data from both sources.

I believe this study is further limited in the following ways:

1. The assumption underlying the central hypothesis may not be correct. . It is possible that the change in the law has had value for people in ways other than court-related behaviors.

2. The size of the samples was small enough to partly affect the validity of the study and to limit its analysis.

3. The time segments that were compared were short.

4. The sample of cases filed under the Act was drawn from a time period too soon after the implementation of the Act. Measurable benefits of the Act may appear after judges, attorneys, and the public have had time to adjust their attitudes to the spirit of the new law. 


\section{CONCLUSIONS}

Given the limitations of this study, I cannot draw powerful conclusions about the value of the Act. Certainly, this exploratory study does not provide hint of credit for the Act excepting that it has brought the law more closely into line with procedure. As a humanistic weapon out to deal the adversary feel to the dissolution process a great blow, the Act is a failure. Certainly, insofar as the body of data represents reality, the central hypothesis stated in null terms is accepted. The Act seems to have made no measureable impact upon families in the process of dissoIution.

That phenomenon may be explained by the old difficulty of trying to legislate effectively in an area where people's values and emotions tend to rule their behaviors. It also may be explained because people who decide to terminate their marriages are culturally defined as failures in one sense. Add to that the very real loss: of their previous support system, however "bad" it may have been, and it is no wonder that they bring to court an ultra-competitive attitude that feeds and feeds on the adversary process. In other words, it seems much to ask of the Act that it remove the competitive component from the dissolution process, when the rest of the culture demands competitive performance.

Specifically, I conclude that the greatest value of 
this study will be if those who read it decide that we need to learn much more, and perhaps make radical changes in our thinking, about ways in which the adversary system may be removed from the process of dissolution of marriage.

III. SUGGESTIONS FOR FURTHER RESEARCH

The limitations of this study are, in themselves, implication for further research with similar objectives. Although obviously requiring considerable time and effort, a study including interviews and follow-ups over time of families in process of dissolution would produce a quality of data not currently available.

In the latter part of the previous chapter, I demonstrated that significant relationships seem to exist between cases requiring returns to court and two other factors. That is only a beginning. Given an expanded data source with many factors to work with, social reseachers may be able to isolate the kind of decisions that will have the desired impact upon the process.

The criticism of traditional adversary divorce sounded meaningful and compelling. The Act was a direct response to those and yet it seems not to be the answer. We must now generate an answer with objective data, not guess again. 
REFERENCES CONSULTED

Bateman, Dorothy E., et al. Changing the Custody of Children Whose Parents Have Been Divorced: A General View of the Process. Portland State University, MSW Thesis May, 1970

Bohannon, Paul (ed.), Divorce and After. New York, Doubleday, 1970.

Brady, Stuart A., "California's Divorce Reform, Its Sociological Implication." Pacific Law Journal, Vol. 1 January, 1970 . p. 223-232.

Brune, George, et al. The Department of Family Services, Court of Domestic Relations, Portland, Oregon: A Report of Its History, Function, and Its Future, Portland State University, 1974.

Cline, David W. and Westman, Jack C., "The Impact of Divorce on the Family," Child Psychiatry and Human Development, $2.2,1971$, p. 78-83.

Crowe, Austin and Harrington, Francis, "New Oregon Dissolution of Marriage Act,'" Legislation, Oregon State Bar 1971

Freeman, Marvin A., et al. Attorney's Guide to Family Law. Act Practice, Regents of the University of California, 1972

Goddard, Wendell H., "A Report on California's New Divorce Law: Progress and Problems," Family Law Quarterly. Vol. 6, Winter 1972 , p. 405-421

Harrington, Francis, "Family Laws of Oregon as Amended in 1973," Oregon State Bar Family Law Handbook.

Heritage, Lena J. (University of Southern Mississippi), "A Study of Selected Factors and their Effects on Postdivorce Ad justment," Dissertation Abstracts International, vol 32(9-a), March, 1972.

Humphrey, Stephen I., "Kentucky Divorce Reform," Journal of Family Law, 12:1, 1972-1973, p. 109-150. 
Kargman, M. W., "There Ought to be a Iawl The Revolution In Divorce Law," Family Coordinator, 22:2, 1973 p. 245248 .

Krom, Howard A., "California Divorce Law Reform: An Historical Analysis," Pacific Law Journal, Vol. 1, January, 1970, p. 147-181.

Leo, Roger J., "Oregon's No-Fault Marriage Dissolution Act," Oregon Law Review, Vol. 51, 1972, p. 715-726.

Maddi, Dorothy I., "The Effect of Conciliation Court Proceedings on Petitions for Dissolution of Marriage," Journal of Family Law, 13:3, 1974, p. 495-566.

O'brien, J. E., "Violence in Divorce Prone Families," Journal of Marriage and the Family, 33:4, November, 1971, p. 692-698. -

Rosenbaum, N. P., "Divorce Reform in England: The Decline of the Matrimonial Offense," Journal of Family Law, $12: 3,1972-1973$, p. 365-389.

Stevenson, Victoria, "Oregon's No-Fault Divorce Law: Effect on Custody, Property Division, and Support," Oregon Law Review, 15:2, 1976, p. 267-277.

Westman, Jack C., "The Psychiatrist and Child Custody Contests," American Journal of Psychiatry, 127:12, June, 1971, p. 1687-1688.

Wheeler, Michael, No-Fault Divorce, Boston, Beacon Press, 1974.

Wolf; E. H., "Divorce Reform Law - A Lesson in Legislative Oversight," Buffalo Law Review, Vol. 22, Fall, 1972 p. 173 .

Zuckman, H. I. and Fox, William F., "The Ferment in Divorce Legislation," Journal of Family Iaw, 12:4, 1972-1973. p. 515-605. 